\title{
Luteolin, quercetin, genistein and quercetagetin inhibit the effects of lipopolysaccharide obtained from Porphyromonas gingivalis in $\mathrm{H} 9 \mathrm{c} 2$ cardiomyoblasts
}

Gloria Gutiérrez-Venegas", Alfredo Torras-Ceballos, Juan Arturo Gómez-Mora and Berenice Fernández-Rojas

\section{* Correspondence:}

gloria@fo.odonto.unam.mx

Laboratorio de Bioquímica de la

División de Estudios de Posgrado

de la Facultad de Odontología,

Universidad Nacional Autónoma de

México Ciudad Universitaria, 04510

México DF, Mexico

\begin{abstract}
Background: One of the microorganisms from dental plaque associated with severe inflammatory responses in infectious endocarditis is Porphyromonas gingivalis. It is a Gram-negative bacteria harvested from chronic periodontitis patients. Lipopolysaccharide (LPS) obtained from P. gingivalis promotes the expressions of interleukin-1 (IL-1), IL-6 and tumor necrosis factor alpha (TNF-a). Flavonoids are thought to participate in processes that control inflammation, such as the expression of cyclooxygenase-2 (COX-2).

Methods: We investigated the effects of luteolin, quercetin, genistein and quercetagetin on cardiomyoblasts treated with LPS alone or in combination with following inhibitors p38 (SB203580), ERK (PD98059), JNK (SP600125) and PKC (Calphostin C) for $1 \mathrm{~h}$. The kinase activation and COX-2 expression levels were determined th the gene and protein levels.

Results: These flavonoids are considered to inhibit the activation of mitogen-activated protein kinase (MAPK) and the degradation of inhibitor of kappa B-alpha (IKB-a). They also play a role in COX-2 expression.
\end{abstract}

Conclusion: We conclude that the tested flavonoids inhibit inflammatory responses induced by LPS in H9c2 cells.

Keywords: Cardiomyoblasts, Flavonoids, Mitogen-activated protein kinase, Lipopolysaccharide

\section{Background}

Poor dental hygiene favors bacterial inflow into the bloodstream of the mouth. Such bacteria can form colonies in the heart valves, causing a local infection called infective endocarditis [1-5]. The significance of bacteremia caused by dental extraction has not yet been fully characterized, but antibiotic prophylaxis has been widely used in its prevention [6].

P. gingivalis is found in dental plaque and associated with chronic periodontitis. LPS obtained from aforementioned bacteria induces pro-inflammatory processes and initiates a wide range of events that trigger destructive developments, but it also induces

(c) The Author(s). 2017 Open Access This article is distributed under the terms of the Creative Commons Attribution 4.0 International License (http://creativecommons.org/licenses/by/4.0/), which permits unrestricted use, distribution, and reproduction in any medium, provided you give appropriate credit to the original author(s) and the source, provide a link to the Creative Commons license, and indicate if changes were made. The Creative Commons Public Domain Dedication waiver (http://creativecommons.org/ publicdomain/zero/1.0/) applies to the data made available in this article, unless otherwise stated. 
continual secretion of several cytokines, such as TNF- $\alpha$ [7], COX-2 [8], interleukin-1beta (IL-1 $\beta$ ) [8] and IL-6 [9], which are determinant molecules for tissue destruction.

Toll-like receptor 4 (TLR4) is a primary receptor for LPS [10]. LPS activates transcription for nuclear factor kappa-light chain-enhancer of activated B cells (NFkB). This transcriptional activity is associated with the expression of genes dependent on this factor and requires the stimulation of MAPK [11-13].

Natural polyphenols found in different plants including vegetables and fruits. It has been claimed these molecules are able to inhibit inflammation in different cells. Figure 1 shows the molecular structure of the flavonoids employed: luteolin, quercetin, genistein and quercetagetin.

Luteolin $\left(3^{\prime}, 4^{\prime}, 5,7\right.$ tetrahydroxyflavone) is an important flavone present in broccoli, pepper, thyme and celery and naturally found in a glycosylated form. Various studies showed that it possesses anti-inflammatory activity due to kinase inhibition and inhibition of proinflammatory substances [14-16] and that it prevents oxidative stress-induced cardiomyoblast apoptosis [17]. In LPS-stimulated murine macrophages of the RAW 264.7 cell line, luteolin inhibited TNF- $\alpha$ and IL- 6 release, tyrosine phosphorylation, NF-kB-mediated gene expression, and protein kinase B (AKT) phosphorylation [18]. Luteolin was more effective than luteolin 7-glucoside, quercetin or genisteineriodictyol, with a 50\% inhibitory concentration $\left(\mathrm{IC}_{50}\right)$ value lesser than $1 \mu \mathrm{M}$ for TNF- $\alpha$ release [19].

Quercetin (3,3', $4^{\prime}, 5,7$-pentahydroxyflavanone) is a flavonol that displays protective effects against oxidative stress-induced cardiomyoblast apoptosis [20-22]. Quercetin inhibits LPS-induced TNF- $\alpha$ production in macrophages [23] in additon to LPSinduced IL-8 production in A549 lung cells [24]. Quercetin can inhibit LPS-induced<smiles>O=c1c(O)c(-c2ccc(O)c(O)c2)oc2cc(O)cc(O)c12</smiles><smiles>O=c1c(O)c(-c2ccc(O)c(O)c2)oc2cc(O)c(O)c(O)c12</smiles>

Quercetin<smiles>CC1=CCc2ccccc2O1</smiles>

Quercetagetin<smiles>O=c1cc(-c2ccc(O)c(O)c2)oc2cc(O)cc(O)c12</smiles>

Genistein

Luteolin

Fig. 1 The chemical structures of quercetin, quercetagetin, genistein and luteolin. The central structure is that of a flavone. It has two phenyl rings ( $A$ and $B$ ) joined by a pyran ring (C). The boxes frame the substituents of their structure with respect to the flavonoid quercetin 
mRNA levels of COX-2, reducing apoptotic neuronal cell death caused by microglial activation [25].

Genistein is an isoflavone (4',5,7-trihydroxyisoflavone,5,7-dihydroxy-3-(4-hydroxyphenyl)-4-H-1-benzopyran-4-one) that diminishes the production of nitric oxide (NO) and prostaglandin E3 in BV2 microglia stimulated with LPS [26]. Quercetagetin (6-hydroxyquercetin) inhibits LPS-mediated COX-2 induction in human gingival fibroblasts [27].

We studied the regulatory roles of luteolin, genistein, quercetin and quercetagetin in the signaling pathways stimulated by LPS treatment in cardiomyoblasts. We found that the studied flavonoids reduced the phosphorylation of LPS-stimulated MAPK and COX-2 expression in a similar fashion.

\section{Methods}

Materials

The H9c2 cell line was obtained from the American Type Culture Collection (ATCC CRL-1446). Dulbecco's modified Eagle's medium (DMEM), fetal bovine serum (FBS), penicillin, streptomycin, trypan blue and Super Script One-Step Reverse transcription-polymerase chain reaction (RT-PCR kits were purchased from Invitrogen (Carslab, CA, USA). Luteolin, genistein, quercetin, quercetagetin, phenylmethylsulfonyl fluoride, sodium dodecyl sulfate (SDS) and ethylene diamine tetraacetic acid (EDTA) tetrazolium salt were obtained from Sigma Aldrich (St. Louis Mo, USA). LPS obtained from $P$. gingivalis (InVivo Gen, San Diego California USA), antibodies against p38, $\gamma$-tubulin, p50, phospho-extracellular signal-regulated kinase (ERK Thr 202/Tyr 204), phospho-p38 (Tyr 182), phospho-AKT (with the Cterminal at Ser 43), COX-2, ІкB $\alpha$, IкB $\beta$ and luminol reagent were purchased from Santa Cruz Biotechnology (Santa Cruz, CA, USA).

\section{Cell culture}

Cells were grown in DMEM with 10\% FBS, $100 \mathrm{U} / \mathrm{ml}$ penicillin, $100 \mu \mathrm{g} / \mathrm{ml}$ streptomycin and $2 \mathrm{mM} \mathrm{L}$-glutamine, incubated at $37{ }^{\circ} \mathrm{C}$ in a humidified atmosphere with $5 \% \mathrm{CO}_{2}$.

\section{Cell treatment}

H9c2 cells were grown overnight on 6-well plates at a concentration of 20,000 cells/ well. After the culture medium was replaced with $2 \%$ SBF medium, cells were treated with flavonoids $(10 \mu \mathrm{M})$ for $1 \mathrm{~h}$ and after that with LPS $(1 \mu \mathrm{g} / \mathrm{ml})$ as indicated in Fig. 2a-d. Experiments were also performed with specific inhibitors against p38 MAPK (50 $\mu \mathrm{M}$ SB203598); MAPK kinase (MEK) 1/2 (10 $\mu \mathrm{M}$ PD98059); c-Jun N-terminal kinases (JNK, $10 \mu \mathrm{M}$ SP600125) or protein kinase C (PKC, $1 \mu \mathrm{M}$ Calphostin C) for $1 \mathrm{~h}$ before LPS exposure. The negative control was cells either untreated or treated with dimethyl sulfoxide (DMSO; Sigma-Aldrich, St Louis MO, USA) at a concentration equal to that found in the flavonoids samples $(0.15 \% \mathrm{v} / \mathrm{v})$. After $4 \mathrm{~h}$ treatment, medium samples were collected for protein expression analysis and after $24 \mathrm{~h}$, for cytokine measurements. Proteins were extracted from cells after a single wash with phosphate-buffered saline (PBS) and the whole cell extract was obtained in lysis buffer. All experiments were repeated at least three times. 

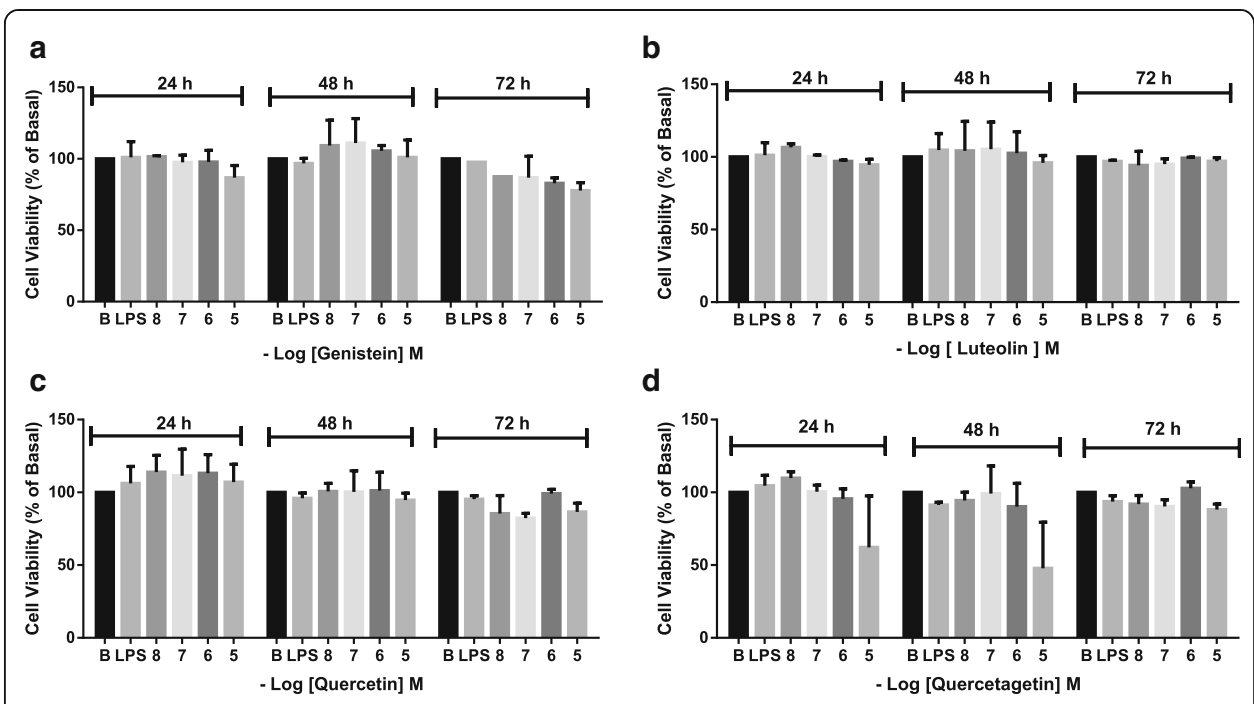

Fig. 2 Flavonoid effect on cell viability. Cell viability in the presence of genistein (a), luteolin (b), quercetin (c) and quercetagetin (d) was evaluated using the MTT assay. H9c2 cells were treated with flavonoid (10 nM -10 $\mu \mathrm{M})$ for 24, 48 and 72 h. Quercetagetin reduced cell viability at the highest concentration at 24 and $48 \mathrm{~h}$ without significant difference. No other flavonoid modified cell viability. The results are expressed as means \pm SEM from at least three independent assays

\section{Cell viability assays}

Cell viability was measured using the 3-(4,5-dimethyldiazol-2-yl)-2,5-diphenyltetrazolium bromide (MTT) assay, which determines mitochondrial activity [28]. Cells $\left(4 \times 10^{5}\right)$ were plated onto 96-well plates, stained for viability with trypan blue, and counted in a Newbauer chamber. After overnight culture, the cells were treated with varying doses of flavonoids $(10 \mathrm{nM}-10 \mu \mathrm{M})$ or LPS for 24,48 or $72 \mathrm{~h}$ at $37{ }^{\circ} \mathrm{C}$ in a $5 \% \mathrm{CO}_{2}$ atmosphere. When incubation was completed, $50 \mu \mathrm{l}$ of MTT $(5 \mathrm{mg} / \mathrm{ml})$ solution in PBS was added to the wells. Plates were then incubated for $4 \mathrm{~h}$ to dissolve purple formazan crystals, $150 \mu \mathrm{l}$ of DMSO was added and the plates were shaken for $30 \mathrm{~min}$. Absorbance was measured at $540 \mathrm{~nm}$ using a microplate reader.

\section{Western blotting analysis}

H9c2 cells $\left(1 \times 10^{4} /\right.$ well $)$ were grown in 6 -well plates (Corning, N.Y., U.S.A.). Briefly, cells were treated with flavonoids $(10 \mu \mathrm{M})$ for $1 \mathrm{~h}$ prior to treatment with LPS $(1 \mu \mathrm{g} /$ $\mathrm{ml})$. Thereafter, the medium was aspirated, the cells were washed twice with PBS, and then put in $50 \mu \mathrm{l}$ of cold lysis buffer consisting of $0.05 \mathrm{~m}$ Tris- $\mathrm{HCl}(\mathrm{pH} 7.4), 0.15 \mathrm{M}$ $\mathrm{NaCl}, 1 \%$ Nonidet P-40, $0.5 \mathrm{M}$ phenylmethylsulfonyl fluoride (PMSF), $10 \mu \mathrm{g} / \mathrm{ml}$ leupeptin, $0.4 \mathrm{mM}$ sodium orthovanadate, $10 \mathrm{mM}$ sodium fluoride and $10 \mathrm{mM}$ sodium pyrophosphate (all from Sigma Chemical Co., St. Louis, MO, USA).

Cells were scraped off, and the lysate was transferred to a micro-centrifuge tube, to be pulse-sonicated $(1 \mathrm{~s} \times 30)$ on ice. The protein concentration was measured using the Bradford protein assay. All samples were separated on a $10 \%$ gel for SDS-PAGE. Proteins were transferred onto polyvinylidene difluoride (PVDF) membranes by electro-blotting (Amersham, Piscataway NJ, USA) using the semi-dry method. Membranes were blocked in a $5 \%$ non-fat milk solution for $1 \mathrm{~h}$ at room temperature before 
being probed with primary antibodies overnight at $4{ }^{\circ} \mathrm{C}$. Primary antibody dilutions were 1:20,000 with tubulin, which was used as an internal loading control. Horseradish peroxidase-linked anti-rabbit secondary antibody $(1: 10,000)$ was used to detect the primary antibody of COX-2, while an anti-mouse secondary antibody $(1: 25,000)$, was used to detect phosphorylated proteins. Immunoreactive bands were developed using a chemiluminescent substrate (Santa Cruz Biotechnology, Inc.). The autoradiograph was obtained with a 5-min exposure. Three different experiments were carried out for each figure. Equal loading of blots was demonstrated by stripping blots and re-probing with antibodies for total $\alpha$-tubulin.

\section{Statistical analysis}

Statistical analysis of densitometric data was performed by determining the integrated optical density (OD) of each sample and using analysis of variance (ANOVA). Any difference between the two groups with a value of $\mathrm{p}<0.05$ was considered significant.

\section{Results}

\section{Chemical structure of flavonoids}

Luteolin was found to have $5,7,3^{\prime}$ and $4^{\prime}$ substituted hydroxyls and a double bond presence at carbons 2 and 3, which are responsible for their multiple pharmacological effects. Genistein is a natural isoflavone compound with hydroxyls groups at positions 5,7 and $4^{\prime}$. It is a specific and potent tyrosine kinase inhibitor that exerts anti-oxidative activity. Quercetin is a flavonol that has an $\mathrm{OH}$ group attached at positions 3, 5, 7, 3', and $4^{\prime}$. Quercetagetin is a flavonol compound that has $3,5,6,7,3^{\prime}$ and $4^{\prime}-\mathrm{OH}$ groups based on the molecular structure of the flavone backbone (2-phenyl-1,4-benzopyrone). It has many effects, including antifungal, antibacterial and antioxidant activities.

\section{Flavonoid effect on cell viability}

We examined the cytotoxicity of luteolin, genistein, quercetin and quercetagetin over a wide concentration range and different periods using an MTT assay on H9c2 cells. Cells were treated with flavonoid $(10 \mathrm{nM}-10 \mu \mathrm{M})$ and incubated for 24, 48 and $72 \mathrm{~h}$. At the concentrations evaluated, flavonoid treatment had no cytotoxic effect. However, at $10 \mu \mathrm{M}$ for 24 or $48 \mathrm{~h}$, quercetagetin reduced $\mathrm{H} 9 \mathrm{c} 2$ viability. Low concentrations of quercetagetin (less than $10 \mu \mathrm{M}$ ) did not have a significant effect on the viability or survival of the H9c2 cells (Fig. 2). Thus, we used $10 \mu \mathrm{M}$ concentrations of flavonoids in subsequent experiments (Fig. 2a-d).

\section{Effects of LPS on the activation of MAPK in H9c2 cells}

H9c2 cells were treated with LPS for the indicated periods and doses. We observed that LPS promoted phosphorylation of MAPK family members, such as ERK1/2 (a kinase activated by mitogens), p38 (a kinase activated by stress), and JNK. Maximal phosphorylation occurred 15 min post-treatment. For ERK, phosphorylation diminished at $60 \mathrm{~min}$, possibly due to the activity of a phosphatase. Membranes were stripped and reprobed with anti-tubulin antibody to confirm equal loading in all lanes. To examine the direct effect of LPS on the activation of ERK1/2 (Fig. 3a), p38 (Fig. 3b) and JNK (Fig. 3c), H9c2 cells were treated with various concentrations of LPS $(0.1-10 \mu \mathrm{g} / \mathrm{ml})$ for 


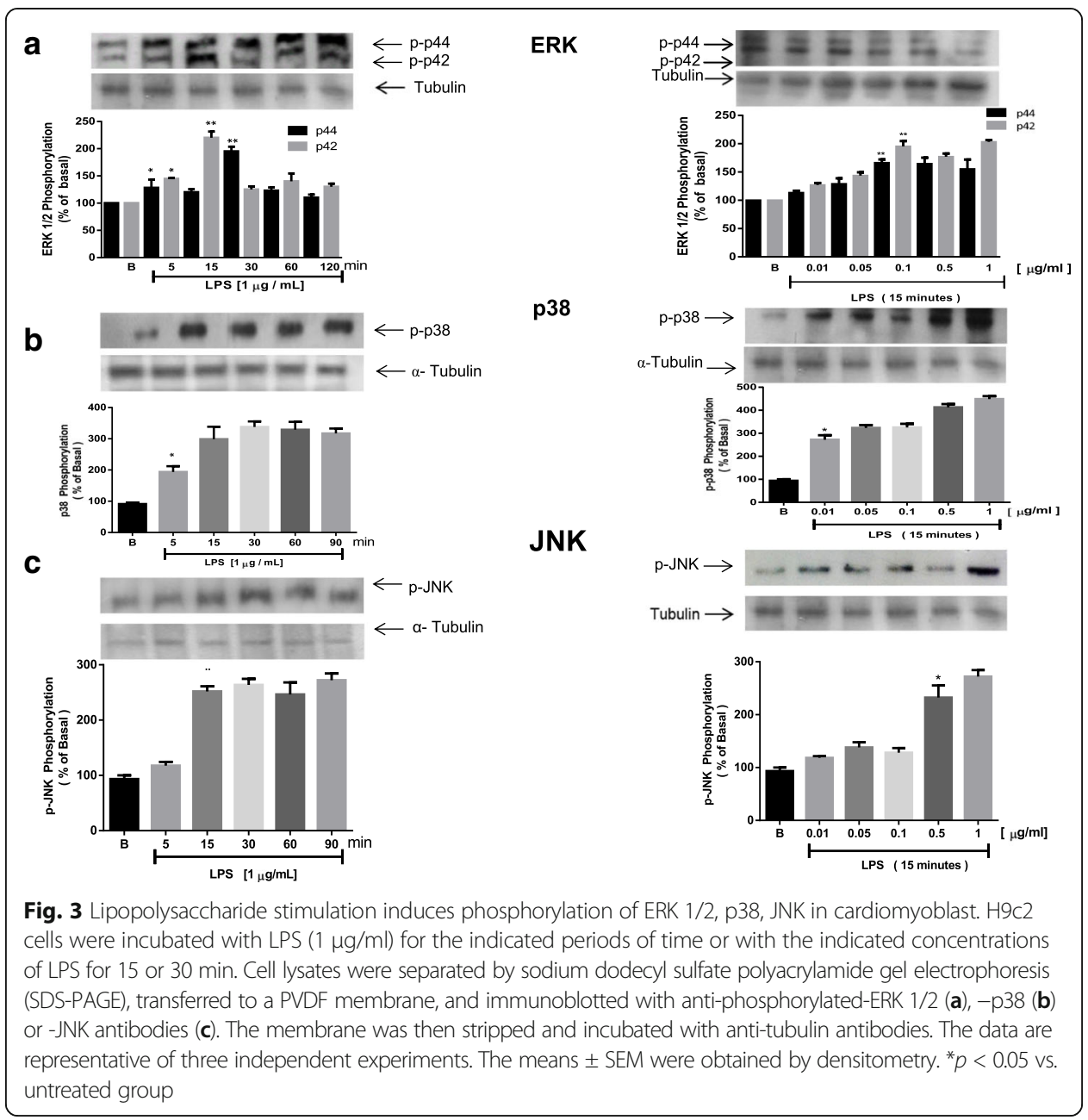

15 min to assess activation. As shown by western blotting (Fig. 3), LPS induced kinase phosphorylation in a dose-dependent manner. In addition, LPS induced kinase phosphorylation at concentrations as low as $0.1 \mu \mathrm{g} / \mathrm{ml}$ and reached a plateau at $5 \mu \mathrm{g} / \mathrm{ml}$.

\section{Effect of flavonoids on LPS-induced MAPK phosphorylation in H9c2 cells}

To determine the effect of flavonoids on LPS-induced ERK1/2 phosphorylation, cells were pre-incubated with the respective flavonoids $(10 \mu \mathrm{M})$ for $1 \mathrm{~h}$ and then treated with LPS $(1 \mu \mathrm{g} / \mathrm{ml})$ for $15 \mathrm{~min}$. Under these conditions, LPS promoted ERK1/2 phosphorylation (p44 and p42). Treatment with flavonoids blocked LPS-induced phosphorylation of ERK1/2. In addition, LPS-mediated ERK1/2 phosphorylation was completely blocked by quercetagetin and by luteolin (Fig. 4a).

We next tested the role of flavonoids in LPS-mediated inhibition of p38 phosphorylation. Treatment with luteolin and quercetagetin completely inhibited p38 phosphorylation, while genistein and quercetin inhibited p38 phosphorylation to a lesser extent (Fig. 4b). 


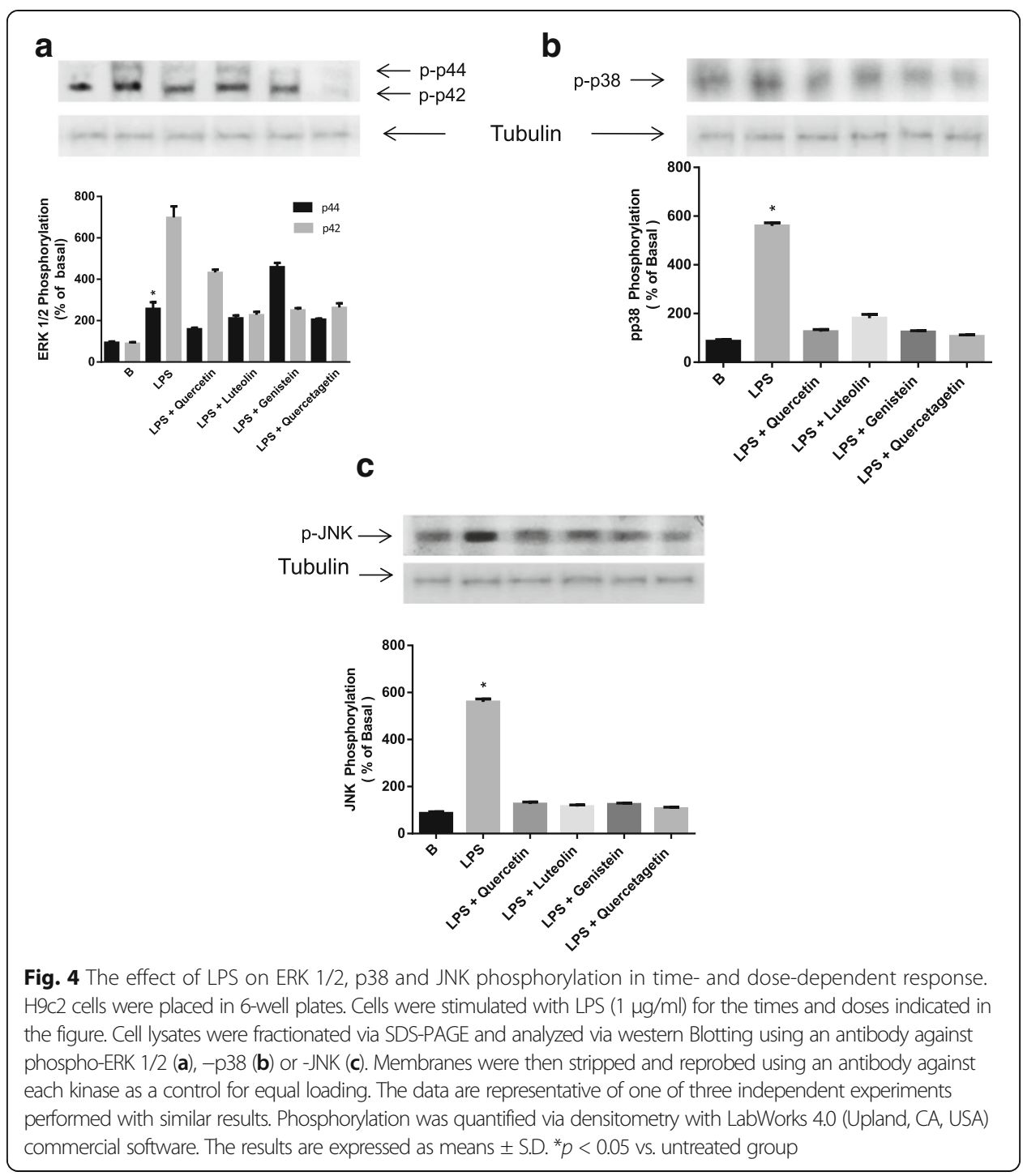

Finally, we evaluated the effect of flavonoids on JNK phosphorylation. LPS induced a 5.5-fold increase in JNK phosphorylation above basal activity in H9c2 cells, while treatment with flavonoids completely inhibited JNK phosphorylation (Fig. 4c).

\section{Inhibition of LPS-induced degradation of ІкB}

To determine whether flavonoids affected the LPS-induced degradation of IkB, we first

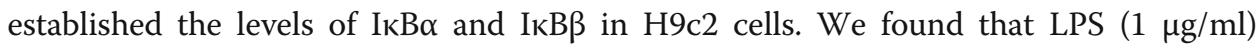
promotes $\mathrm{I} k \mathrm{~B} \alpha$ degradation in a time-dependent fashion and $\mathrm{I} \kappa \mathrm{B} \alpha$ decreased after $60 \mathrm{~min}$ of LPS incubation (Fig. 5a). Maximal phosphorylation was observed after 15 min of treatment. LPS did not show effect on IкB $\beta$ (Fig. 5b). Western blot analysis of cell extracts with IkB $\alpha$-specific antibodies showed that treatment with flavonoids and LPS blocked this reduction in a concentration-dependent manner (Fig. 5c). Treatment with flavonoids blocked LPS-induced IkB $\alpha$ degradation. Luteolin significantly inhibited LPS-induced ІкB degradation (Fig. 5d). 


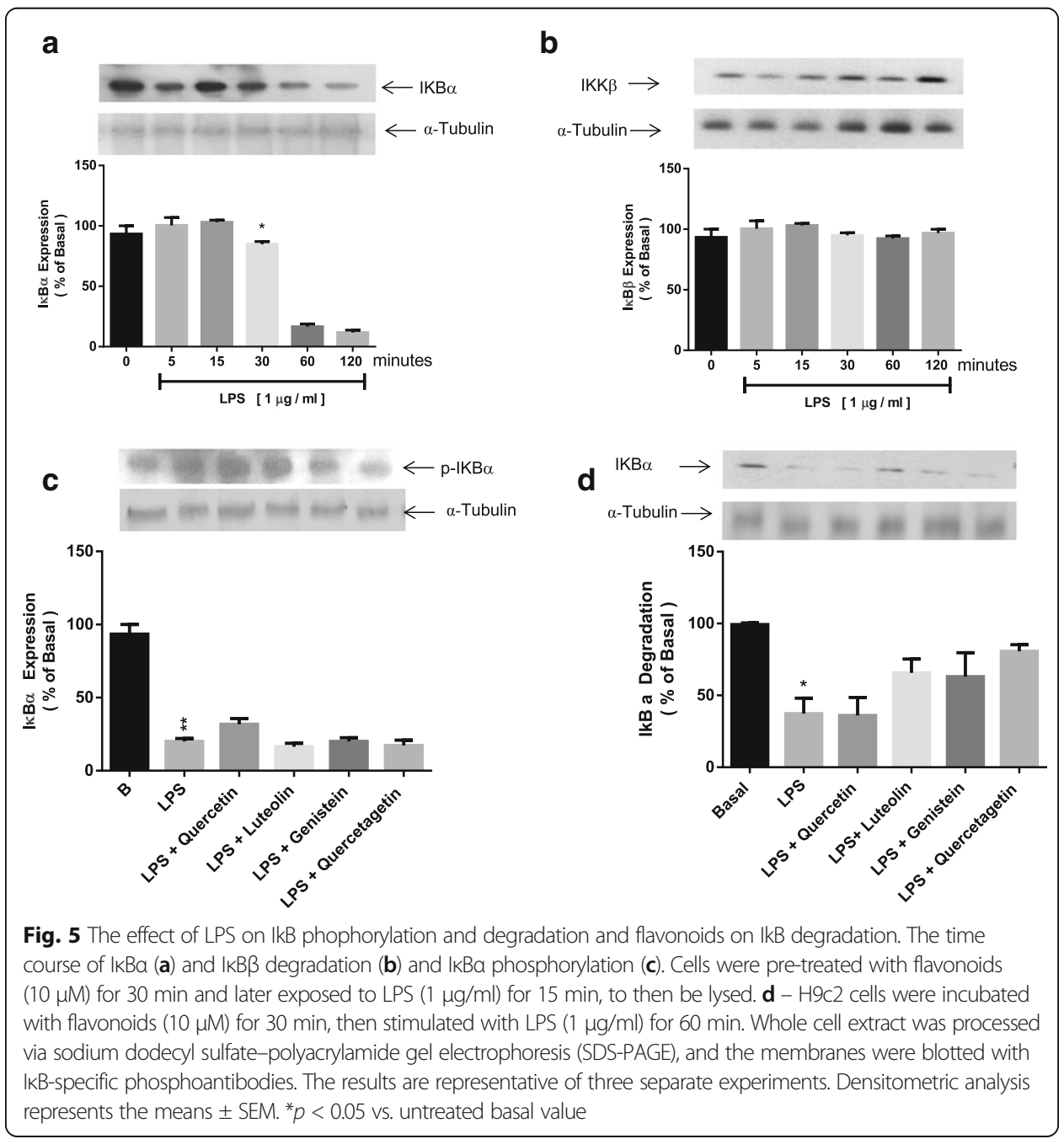

\section{Flavonoids reduce LPS-induced inflammatory COX-2 protein expression}

We investigated the anti-inflammatory properties of flavonoids. During inflammation, large amounts of pro-inflammatory cytokines are synthesized. The western blot result showed that after $12 \mathrm{~h}$ treatment with LPS and flavonoids, these compounds significantly inhibited the expression of COX-2 induced by LPS (Fig. 6a). Furthermore, western blotting analysis showed that LPS treatment stimulated COX-2 expression, but that this LPS-induced expression was significantly downregulated by luteolin, genistein and quercetagetin. Quercetin was found to have no effect (Fig. 6b).

\section{p38 and JNK are involved in LPS-induced COX-2 expression}

We evaluated the effect of inhibitors on COX-2 expression. Fig. 6c shows that LPS treatment stimulated COX-2 expression, which was significantly downregulated by SB203580 and SP600125. These data suggest that p38 and JNK are involved in COX-2 expression induced by LPS in H9c2 cells. However, ERK and PKC showed no effect on COX-2 expression. The results strongly suggest that p38 and JNK are involved in COX-2 expression. 


\section{a}

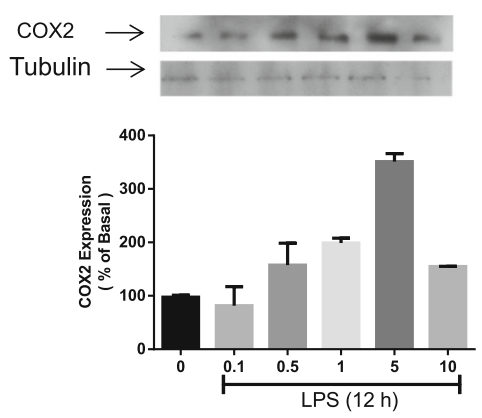

b

C
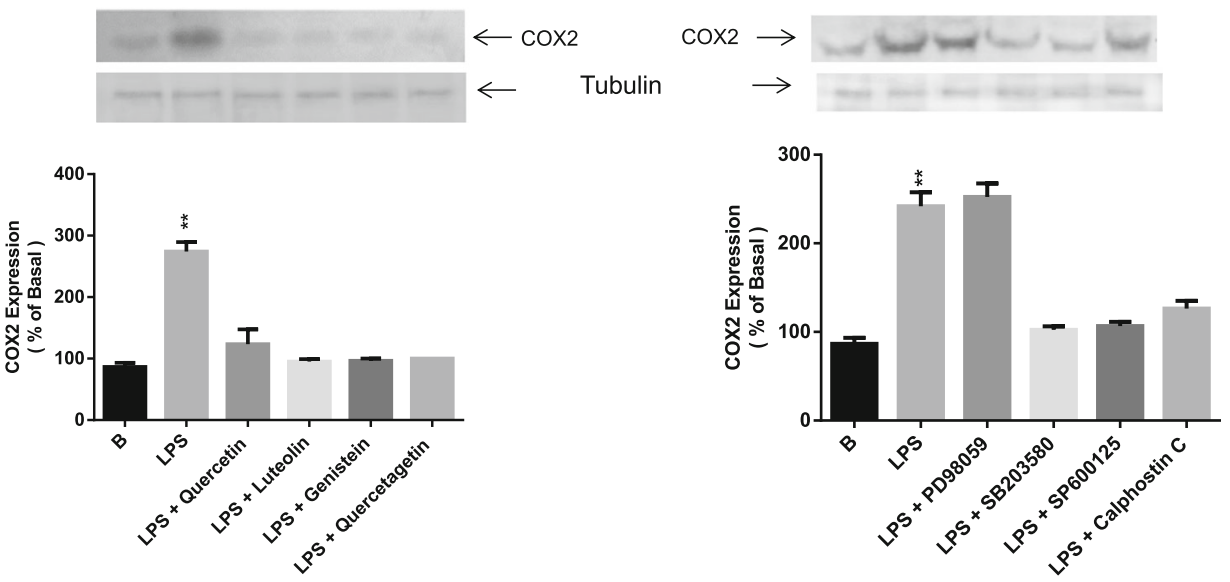

Fig. 6 Effect of LPS and flavonoids on COX-2 expression. a - H9c2 cells were incubated with LPS at different doses. $\mathbf{b}$ - H9c2 cells were pretreated with flavonoids $(10 \mu \mathrm{M})$ for $1 \mathrm{~h}$ and then incubated with LPS $(1 \mu \mathrm{g} / \mathrm{ml})$ for 12 h. c - H9c2 cells were pretreated with different inhibitors and then treated with LPS (1 $\mu \mathrm{g} / \mathrm{ml})$. The lysates of the cells were processed via sodium dodecyl sulfate-polyacrylamide gel electrophoresis (SDS-PAGE), and the membranes were blotted with COX-2-specific antibodies. The results are representative of three separate experiments. Tubulin was used as an internal control for western blot analysis. Statistical significance was determined with a two-way ANOVA test. ${ }^{*} p<0.05$ vs. untreated group

\section{Discussion}

This study demonstrated that LPS induced COX-2 expression in H9c2 cells, but that flavonoid pretreatment attenuated the inflammatory response and affected the MAPK pathway. The cardioprotective activity due to flavonoids downregulating COX-2 expression may be due to suppression of the MAPK signaling pathway. Chronic action of LPS disturbs the balance of tissue homeostasis, resulting in the accumulation of inflammatory response [23].

Flavonoids are widely found in the plant kingdom. Various studies have shown that they possess anti-inflammatory properties. Luteolin, genistein, quercetin and quercetagetin inhibited LPS-induced expression of inflammatory mediators such as TNF $\alpha$ and NO by suppressing NF-kB activation [22-24]. Furthermore, these flavonoids exerted inhibitory effects on IkB degradation.

In the LPS signaling pathways, four kinds of flavonoid may inhibit MAPK activation. Of the four flavonoids analyzed in this study, only the activity of luteolin had previously been reported on. In an experiment using human gingival fibroblasts, luteolin was shown to attenuate PGE2 and inhibit COX-2 gene expression. However, we found no 
effect of quercetin on COX-2 expression. We also reported that luteolin inhibited nuclear localization and transcriptional activation of NF-kB [24].

Xagogari et al. [12] also reported that luteolin inhibited IL-6- and TNF- $\alpha$-mediated nuclear localization and transcriptional activation of NF- $\kappa$ B. All four kinds of flavonoid exert anti-inflammatory activity by inhibiting NF-kB activation in H9c2 stimulated with LPS.

Because LPS is an activator of IkB, we studied the inhibitory effects of these four flavonoids on LPS-induced IkB phosphorylation and degradation in H9c2 cells. A previous study reported that LPS promotes ІкB- $\alpha$ phosphorylation and degradation. Here, we found that flavonoids blocked $\mathrm{I} \kappa \mathrm{B} \alpha$ degradation and demonstrated that flavonoids strongly inhibited IкB- $\alpha$ activity in the cardiomyoblast cell line, H9c2. Some earlier reports [25-31] showed moderate inhibitory inflammatory activities for different flavonoids, but quercetin yielded the lowest level of inhibition.

Our investigation showed that flavonoids inhibit COX-2 production in LPS-treated H9c2 cells. The strongly active flavonoids possessed a C-2,3 double bond and 6-hydroxyl group in the A-ring, which suggests that the 6-hydroxyl moiety in the A-ring reduces COX-2 expression induced by LPS. For example, luteolin inhibits COX-2 expression to a greater degree than flavonol derivatives, such as quercetin.

\section{Conclusion}

Our results show that flavonoids regulate the inflammatory response in cardiomyoblast. Of the assessed flavonoids, luteolin exhibited the best effects. Quercetagetin and genistein showed similar effects and quercetin had the lowest effect. Further studies might be needed to determine the target of luteolin in cardiomyoblast and evaluate its potential as a treatment for the cardiac inflammatory response.

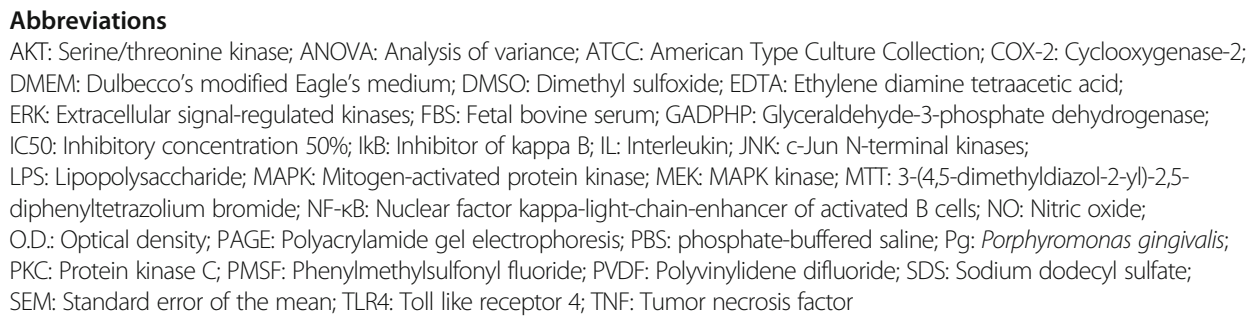


Competing interests

The authors declare that they have no competing interests.

\section{Publisher's Note}

Springer Nature remains neutral with regard to jurisdictional claims in published maps and institutional affiliations.

Received: 13 March 2017 Accepted: 21 August 2017

Published online: 04 September 2017

\section{References}

1. Mitchell J, Siboo IR, Takamatsu D, Chambers HF, Sullam PM. Mechanism of cell surface expression of the Streptococcus Mitis platelet binding proteins PbIA and PbIB. Mol Microbiol. 2007;64(3):844-57.

2. Bavunoglu I, Sahin S, Yilmaz M, Toptas T, Tabak F, Tunckale A. Native triple-valve endocarditis caused by penicillinresistant streptococcus sanguis. Nat Clin Pract Cardiovasc Med. 2007;4(6):340-3.

3. Sykes RB, Farrington E. Prophylaxis for bacterial endocarditis prior to dental procedures in children. J Pediatr Health Care. 2007;21(4):256-8.

4. da Silva DB, Souza IP, Cunha MC. Knowledge, attitudes and status of oral health in children at risk for infective endocarditis. Int J Paediatr Dent. 2002;12(2):124-31.

5. Lockhart PB, Brennan MT, Thornhill M, Michalowicz BS, Noll J, Bahrani-Mougeot FK, Sasser HC. Poor oral hygiene as a risk factor for infective endocarditis-related bacteremia. J Am Dent Assoc. 2009;140(10):1238-44.

6. Lefort A. Dental extraction and infective endocarditis prophylaxis: current recommendations. Rev Med Interne. 2008;29(7):550-3.

7. Myers KJ, Murthy S, Flanigan A, Witchell DR, Butler M, Murray S, Siwkowski A, Goodfellow D, Madsen K, Baker B. Antisense oligonucleotide blockade of tumor necrosis factor-alpha in two murine models of colitis. J Pharmacol Exp Ther. 2003;304(1):411-24.

8. Abreu MT, Vora P, Faure E, Thomas LS, Arnold ET, Arditi M. Decreased expression of toll-like receptor-4 and MD-2 correlates with intestinal epithelial cell protection against dysregulated proinflammatory gene expression in response to bacterial lipopolysaccharide. J Immunol. 2001;167(3):1609-16.

9. Müller-Werdan U, Schumann H, Loppnow H, Fuchs R, Darmer D, Stadler J, Holtz J, Werdan K. Endotoxin and tumor necrosis factor alpha exert a similar proinflammatory effect in neonatal rat cardiomyocytes, but have different cardiodepressant profiles. J Mol Cell Cardiol. 1998;30(5):1027-36.

10. Khan S, Ohoi RJ, Shehzad O, Kim HP, Islam MN, Choi JS, Kim YS. Molecular mechanism of capillarisin-mediated inhibition of MyD88/TIRAP inflammatory signaling in in vitro and in vivo experimental models. J Ethnopharmacol. 2013;145:626-37

11. Li FF, Yuan Y, Liu Y, Wu QQ, Jiao R, Yang Z, Zhou MQ, Tang QZ. Pachymic acid protects H9c2 cardiomyocytes from lipopolysaccharide-induced inflammation and apoptosis by inhibiting the extracellular signal-regulated kinase 1/2 and p38 pathways. Mol Med Rep. 2015;12(2):2807-13.

12. Xagorari A, Papapetropoulos A, Mauromatis A, Economou M, Fotsis T. Roussos. C. Luteolin inhibits an endotoxinstimulated phosphorylation cascade and proinflammatory cytokine production in macrophages. J Pharmacol Exp Ther. 2001;296(1):181-7.

13. Frazier WJ, Xue J, Luce WA, Liu Y. MAPK signaling drives inflammation in LPS-stimulated cardiomyocytes: the route of crosstalk to G-protein-coupled receptors. PLoS One. 2012;7(11):e50071.

14. Kim SH, Shin KJ, Kim D, Kim YH, Han MS, Lee TG, Kim E, Ryu SH, Suh PG. Luteolin inhibits the nuclear factor-kappa B transcriptional activity in rat-1 fibroblasts. Biochem Pharmacol. 2003;66(6):955-63.

15. Yamashita N, Kawanishi S. Distinct mechanisms of DNA damage in apoptosis induced by quercetin and luteolin. Free Radic Res. 2000;33(5):623-33.

16. Chen CY, Peng WH, Tsai KD, Hsu SL. Luteolin suppresses inflammation-associated gene expression by blocking NF-kappaB and AP-1 activation pathway in mouse alveolar macrophages. Life Sci. 2007;81(23-24):1602-14.

17. Yang JT, Qian LB, Zhang FJ, Wang J, Ai H, Tang LH, Wang HP. Cardioprotective effects of luteolin on ischemia/ reperfusion injury in diabetic rats are modulated by eNOS and the mitochondrial permeability transition pathway. J Cardiovasc Pharmacol. 2015;65(4):349-56.

18. Xagorari A, Roussos C, Papapetropoulos A. Inhibition of LPS-stimulated pathways in macrophages by the flavonoid luteolin. Br J Pharmacol. 2002;136(7):1058-64.

19. Ko WC, Shih CM, Lai YH, Chen JH, Huang HL. Inhibitory effects of flavonoids on phosphodiesterase isozymes form guinea pig and their structure-activity relationships. Biochem Pharmacol. 2004;68(10):2087-94.

20. Angeloni C, Leoncinci E, Malaguti M, Angelini S, Hrelia P, Hrelia S. Role of quercetin in modulating rat cardiomyocyte gene expression profile. Am J Physiol Heart Circ Physiol. 2008;294(3):H1233-43.

21. Tang L, Peng Y, Xu T, Yi X, Liu Y, Luo Y, Yin D, He M. The effects of quercetin protect cardiomyocytes from a/R injury is related to its capability to increasing expression and activity of PKC $\varepsilon$ protein. Mol Cell Biochem. 2013; 382(1-2):145-52.

22. Liu X, Yu Z, Huang X, Gao Y, Wang X, Gu J, Xue S. Peroxisome proliferator-activated receptor Y (PPARY) mediates the protective effect of quercetin against myocardial ischemia-reperfusion injury via suppressing the NF-kB pathway. Am J Transl Res. 2016;8(12):5169-86.

23. Manjeet KR, Ghosh B. Quercetin inhibits LPS-induced nitric oxide and tumor necrosis factor-a production in murine macrophages. In J Immunopharmacol. 1999 Jul;21(7):435-43.

24. Lee SG, Kim M, Kim CE, Kang J, Yoo H, Sung SH, Lee M. Quercetin 3,7-O-dimethyl ether from Siegesbeckia pubescens suppress the production of inflammatory mediators in lipopolysaccharide-induced macrophages and colon epithelial cells. Biosci Biotechnol Biochem. 2016;13:1-7. 
25. Endale M, Park SC, Kim S, Kim SH, Yang Y, Cho JY, Rhee MH. Quercetin disrupts tyrosine-phosphorylated phosphatidylinositol 3-kinase and myeloid differentiation factor-88 association, and inhibits MAPK/AP-1 and IKK NF-kB-induced inflammatory mediators production in RAW 264.7 cells. Immunobiology. 2013;218(12):1452-67.

26. Jeong JW, Lee HH, Han MH, Kim GY, Kin GY, Kim WJ, Choi YH. Anti-inflammatory effects of genistein via suppression of the toll-like receptor 4-mediated signaling pathway in lipopolysaccharide-stimulated BV2 microglia. Chem Biol Interact. 2014;212:30-9.

27. Gutiérrez-Venegas $\mathrm{G}$, Jiménez-Estrada M, Maldonado $\mathrm{S}$. The effect of flavonoids on transduction mechanisms in lipopolysaccharide-treated human gingival fibroblasts. Int Immuno Pharmacol. 2007;7(9):1199-210.

28. Gutiérrez-Venegas G, González-Rosas Z. Apigenin reduce lipoteichoic acid-induced inflammatory response in rat cardiomyoblast cells. Arch Pharm Res. 2017;40(2):240-9.

29. Chomczynski P, Sacchi N. Single-step method of RNA isolation by acid guanidinium thiocyanate-phenolchloroform extraction. Anal Biochem. 1987;162(1):156-9.

30. Bradford Sanders D, Hunter K, Wu Y, Jablonowski C, Bahl JJ, Larson DF. Modulation of the inflammatory response in the cardiomyocytes and macrophage. J Extra Corpor Technol. 2001;33(3):167-74.

31. Gutiérrez-Venegas G, Contreras-Sánchez A. Luteolin and fisetin inhibit the effects of lipopolysaccharide obtained from Porphyromonas gingivalis in human gingival fibroblasts. Mol Biol Rep. 2013;40(1):477-85.

\section{Submit your next manuscript to BioMed Central and we will help you at every step:}

- We accept pre-submission inquiries

- Our selector tool helps you to find the most relevant journal

- We provide round the clock customer support

- Convenient online submission

- Thorough peer review

- Inclusion in PubMed and all major indexing services

- Maximum visibility for your research

Submit your manuscript at www.biomedcentral.com/submit 